\title{
Recent advances in the clinical management of autosomal dominant polycystic kidney disease [version 1; peer review: 2
}

\section{approved]}

\section{Roser Torra}

Inherited Renal Disorders, Nephrology Department, Fundacio Puigvert, Barcelona, 08025, Spain

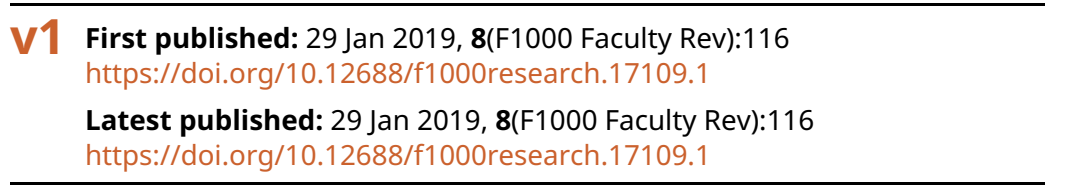

\section{Abstract}

Autosomal dominant polycystic kidney disease (ADPKD) is a genetic systemic disorder causing the development of renal and hepatic cysts and decline in renal function. It affects around 1 in 1,000 live births. Early hypertension and progressive renal failure due to massive enlargement of cysts and fibrosis are hallmarks of the disease. This article reviews recent advances in ADPKD and focuses mainly on diagnosis, management, and prediction of the course of the disease.

Keywords

ADPKD, diagnosis, management, treatment, prediction

\section{Open Peer Review}

Approval Status

1

2

\section{version 1}

$29 \operatorname{Jan} 2019$

Faculty Reviews are review articles written by the prestigious Members of Faculty Opinions. The articles are commissioned and peer reviewed before publication to ensure that the final, published version is comprehensive and accessible. The reviewers who approved the final version are listed with their names and affiliations.

1. Chang-Lin Mei, Shanghai Changzheng Hospital, Second Military Medical University, Shanghai, China

2. John Sayer (iD), Newcastle University, Newcastle upon Tyne, UK

Any comments on the article can be found at the end of the article. 
Corresponding author: Roser Torra (rtorra@fundacio-puigvert.es)

Author roles: Torra R: Conceptualization, Project Administration, Resources, Supervision, Visualization, Writing - Original Draft Preparation, Writing - Review \& Editing

Competing interests: The author has received speaking fees and travel funding from Otsuka pharmaceutical. The author was member of the IDMC of the TEMPO trial.

Grant information: This work was funded by the ISCIII: RETIC REDINREN RD16/0009 FIS FEDER FUNDS (PI15/01824 and PI16/01998) and the Catalan Government (AGAUR 2014/SGR-1441).

The funders had no role in study design, data collection and analysis, decision to publish, or preparation of the manuscript.

Copyright: $\odot 2019$ Torra R. This is an open access article distributed under the terms of the Creative Commons Attribution License, which permits unrestricted use, distribution, and reproduction in any medium, provided the original work is properly cited.

How to cite this article: Torra R. Recent advances in the clinical management of autosomal dominant polycystic kidney disease [version 1; peer review: 2 approved] F1000Research 2019, 8(F1000 Faculty Rev):116 https://doi.org/10.12688/f1000research.17109.1

First published: 29 Jan 2019, 8(F1000 Faculty Rev):116 https://doi.org/10.12688/f1000research.17109.1 


\section{Introduction}

Autosomal dominant polycystic kidney disease (ADPKD) is the most common monogenic cause of kidney failure, occurring in more than 1 in 400 to 1,000 live births and accordingly representing a major socioeconomic medical problem globally ${ }^{1}$. ADPKD arises owing to mutations in the PKDl gene (about $85 \%$ of cases) or the PKD2 gene (about $15 \%$ of cases), which encode the proteins polycystin-1 (PC1) and -2 (PC2), respectively ${ }^{2,3}$. Compared with patients who have PKD1 mutations, those with PKD2 mutations have a milder phenotype and reach end-stage renal disease (ESRD) about 20 years later ${ }^{4-6}$. ADPKD is characterized by progressive development and enlargement of cysts in all nephron segments but preferentially in the collecting duct, and ESRD occurs in $50 \%$ of patients by the age of 60 years ${ }^{1}$. It is associated with cyst formation in other organs, primarily the liver and pancreas, and with cardiovascular anomalies such as intracranial arterial aneurysms and vascular dissections. Huge variation is observed in disease phenotype and progression, even within families; the reason for this is poorly understood, but genetic modifiers, including hypomorphic alleles, probably play a significant role.

Although a definitive curative treatment is not currently available, there is a disease-modifying therapy using a V2 receptor antagonist (tolvaptan $)^{7,8}$. This article guides the reader through recent achievements, and the clinical consequences, within the field of ADPKD.

\section{Genetics and genetic testing}

Mutations in other genes, such as GANAB and DNAJB11, have recently been identified in a small subgroup of patients ${ }^{9,10}$, but the phenotypes related to these mutations are not exactly the same as those caused by mutations in PKD1 or PKD2. This may suggest that, instead of using the name "ADPKD", it would be appropriate to name these diseases after the mutated gene, as has been done, for example, for ADTKD ${ }^{11}$. Whereas mutations in $G A N A B$ give rise to a mild form of cystic disease that does not progress to $\mathrm{ESRD}^{9}$, mutations in DNAJB11 cause cystic disease in the context of which ESRD may develop in the absence of marked kidney enlargement ${ }^{10}$.

Genetic testing has undergone remarkable progress, as is very evident if one considers the case of ADPKD. When the PKDI and $P K D 2$ genes were first identified, genetic testing was performed by means of linkage analysis ${ }^{5}$. Not only was this time consuming but also, more importantly, several affected and non-affected family members were needed in order to identify the risk haplotype. As soon as the PKDl gene was identified, it became evident that genetic testing for the gene would be burdensome owing to the large transcript size $(>14 \mathrm{~kb})$ and reiteration of the genomic area encoding about $75 \%$ of the protein on the same chromosome ${ }^{12}$. The group of Harris then developed a technique that used long-range polymerase chain reaction and benefited from the few non-repeated nucleotides ${ }^{13}$. Although this allowed diagnosis of a single individual, it remained time consuming and was also expensive. Over the past 3 years, nextgeneration sequencing (NGS) has changed the scenario ${ }^{14-16}$. The use of NGS for genetic diseases such as ADPKD has reduced costs, improved sensitivity, and reduced turnaround time ${ }^{17,18}$.
A further advantage of this relatively new technique is that gene panels or whole exome sequencing can be used, allowing the detection of mutations in ultrarare genes that account for a very small number of cases of renal cystic disease ${ }^{17}$. The drawback of testing PKD1 is the huge number of variants of unknown significance (VUSs) that can be identified, around 10 per patient ${ }^{18}$. Some of these VUSs have previously been published as mutations, but for many pathogenicity is still to be elucidated ${ }^{19}$. This is of the utmost relevance when a patient seeks preimplantation genetic diagnosis (PGD) or when a disease-modifying treatment for ADPKD can be offered but there is uncertainty over the diagnosis. PGD has evolved over recent years to become a valuable technique to offer patients with severe genetic diseases, although there are ethical issues regarding its use for non-severe genetic diseases. ADPKD is halfway between these categories, and genetic counseling is highly recommended to ensure sound understanding of the pros and cons of such a procedure $^{20}$. Probably, each case or family should be counseled differently according to the severity of the disease, but patient attitudes to PGD vary considerably depending on how well the family is dealing with the disease, religious aspects, age, disease severity, and so on.

\section{Progression of autosomal dominant polycystic kidney disease}

A large number of factors have been identified as influencing disease progression ${ }^{21}$, and whereas some are modifiable, many are $\operatorname{not}^{22}$. Among the latter are male sex, PKDl mutations (worse if protein-truncating (PT)), early development of renal symptoms, early detection of high blood pressure ${ }^{23}$, and large kidney volumes in relation to age and height ${ }^{24,25}$. Modifiable factors that should be highlighted in patients with ADPKD include smoking; blood pressure; lipid levels; water, protein, and calorie intake; and body mass index (BMI) ${ }^{26-31}$. Also, some biomarkers, such as MCP-1, FGF23, and copeptin, have been found to be predictive factors of ADPKD progression ${ }^{32-34}$.

The prediction of which patients will have a rapid progression is crucial not only for the decision of whether to use a diseasemodifying drug but also for the recruitment of patients to clinical trials ${ }^{35}$. Although in the past few years many attempts have been made to provide tools predictive of rapid disease progression, to date there is no gold standard. Some of these predictive tools employ imaging; an example is the Mayo Clinic ADPKD calculator, which uses the height-adapted total kidney volume (htTKV) to classify patients into one of five classes (A-E) on the basis of growth rates: less than $1.5 \%, 1.5-3 \%, 3-4.5 \%, 4.5-6 \%$, or more than $6 \%$ per year ${ }^{36}$. Measuring TKV for use as a prognostic biomarker does not require high precision. Measurement by the ellipsoid equation as well as by means of various imaging modalities is possible ${ }^{27,37}$. Another imaging approach that can be used to predict PKD progression involves the measurement of renal length. Bhutani et al. demonstrated that a renal diameter of $16.8 \mathrm{~cm}$ is predictive of chronic kidney disease (CKD) stage 3 within 8 years $^{38}$. An alternative to imaging-based prognostic strategies is the Predicting Renal Outcome in Polycystic Kidney Disease (PROPKD) scoring system, as shown in a large cohort from Brittany, France ${ }^{23}$. This scoring system uses both clinical and genetic data to stratify risk of disease progression. Patients 
may reach a score suggestive of rapid progression if they have hypertension or early urinary symptoms before the age of 35 years plus a PT mutation. Male sex is also included in the scoring system. Obvious drawbacks of this predictive tool are the need to perform genetic testing, which may not be available in many centers, and the impossibility of employing it in patients younger than 35 who are asymptomatic. In addition, it is subject to the need to establish a relationship between early symptoms and ADPKD and the limitation that many rapid progressors with PT mutations do not develop early symptoms.

The European Renal Association-European Dialysis and Transplant Association (ERA-EDTA) Working Groups on Inherited Kidney Disorders and European Renal Best Practice (WGIKD/ ERBP) developed a hierarchical decision-making algorithm that may offer guidance on the identification and prediction of rapid disease progression in patients with ADPKD and subsequently identify candidates for tolvaptan treatment ${ }^{39}$. When this algorithm was tested in a cohort of 305 patients, it was found that $15.7 \%$ fulfilled the ERA-EDTA criteria and that the overall proportion of patients with rapid progression rose to $27 \%$ upon incorporation of expanded criteria based on data from the REPRISE (Replicating Evidence of Preserved Renal Function: an Investigation of Tolvaptan Safety and Efficacy in ADPKD) trial ${ }^{40}$ (that is, age of less than 56 years and estimated glomerular filtration rate $[\mathrm{eGFR}]$ of more than $\left.30 \mathrm{~mL} / \mathrm{min} / \mathrm{m}^{2}\right)^{41}$. This study, together with a recent assessment of an unpublished large series of patients, calls into question the suitability of the algorithm, especially in its first steps when limiting for age/eGFR and using retrospective eGFR. Each country, even region, in Europe has either approved the use of the drug on these terms or proposed some changes. For example, the National Institute for Health and Care Excellence (NICE) decision in the UK was to treat on the basis of these criteria but only patients with CKD stage 2 to 3 without limiting age, whereas in Scotland they approved its use in stage 1 . In the US, the preferred approach for definition of a rapid progressor is based on htTKV, age, and eGFR, basically using the Mayo ADPKD calculator ${ }^{42}$. Risk assessment in ADPKD is an evolving process that will undergo further refinement as new clinical data are obtained and prediction tools are developed. The performance of risk assessment guidelines needs to be evaluated and validated by real-life clinical data, but it is probable that the use of a composite tool including age, renal function, imaging, family history and possibly genetic testing will be able to define rapid progression very accurately.

\section{Basic renal protective measures}

Based on the HALT-PKD (Halt Progression of Polycystic Kidney Disease) trial, the recommendations regarding blood pressure control for ADPKD were recently lowered ${ }^{26}$. The target should now be $95-110 / 60-75 \mathrm{mmHg}$ in 15 - to 49-year-old patients with an eGFR of more than $60 \mathrm{~mL} / \mathrm{min} / 1.73 \mathrm{~m}^{2}$. Firstline management of hypertension should include a blocker of the renin-angiotensin-aldosterone system (angiotensin-converting enzyme inhibitors and angiotensin-II receptor blockers $)^{27}$. Second- and third-line treatments should be diuretics and beta-blockers. Calcium channel blockers (particularly the dihydropyridine class) should be considered if blood pressure is not controlled by the other agents ${ }^{27}$. The CRISP (Consortium for Radiologic Imaging Studies of Polycystic Kidney Disease) and HALT studies suggest that moderate dietary sodium restriction $(2.3-3 \mathrm{~g})$ be recommended to patients with $\mathrm{ADPKD}^{22}$.

In patients with cyst infection, a positron emission tomography/ computed tomography scan is recommended to enable determination of the location of cysts for the purpose of diagnosis or drainage $e^{43}$. Fluoroquinolones remain the first-line antibiotic treatment, but their side effects and the increasing prevalence of fluoroquinolone-resistant Gram-negative bacilli mean that cyst infections frequently represent a very large burden.

Until more information becomes available $\mathrm{e}^{44,45}$, moderate enhancement of hydration, spread out over the course of 24 hours, is recommended with the goal of maintaining an average urine osmolality of not more than $280 \mathrm{mOsm} / \mathrm{L}^{27,46}$.

Based on experimental studies and lessons learned from CKD in general, a daily protein intake of $0.8-1.0 \mathrm{~g} / \mathrm{kg}$ ideal body weight seems appropriate in $\mathrm{ADPKD}^{27}$. Although protein-restricted diets are usually already low in phosphorus, patient education on the need to avoid processed foods that contain readily absorbed inorganic phosphates is appropriate. Sodium bicarbonate supplementation is recommended in order to treat metabolic acidosis, and the aim is to maintain the plasma bicarbonate level at a minimum of $22 \mathrm{mmol} / \mathrm{L}^{27}$.

Mild to moderate food restriction has been found to markedly reduce cystogenesis in animal models of $\mathrm{PKD}^{47,48}$. This fact, together with evidence that excess food intake has a detrimental effect both in PKD trials and in CKD in general, means that moderation of caloric intake and avoidance of an above-average BMIshould be recommended to patients with $\mathrm{ADPKD}^{29}$.

A small trial with statins in children has yielded positive results $^{49}$, but a post-hoc analysis of the HALT-PKD trials failed to demonstrate a benefit of statin therapy on renal outcomes ${ }^{50}$. However, evidence in $\mathrm{ADPKD}^{22,31}$, and in CKD in general, indicates that it is appropriate to keep the low-density lipoprotein (LDL) cholesterol level at not more than $100 \mathrm{mg} / \mathrm{dL}$.

\section{Disease-modifying treatments}

In the TEMPO (Tolvaptan Efficacy and Safety in Management of Autosomal Dominant Polycystic Kidney Disease and Its Outcomes) 3:4 trial, the vasopressin receptor antagonist tolvaptan was shown to slow the growth of cystic kidneys and the deterioration of renal function ${ }^{7}$. Based on these results, the European Medicines Agency in 2015 approved tolvaptan to slow the progression of cyst development and renal insufficiency in ADPKD in adults with CKD stages $1-3$ at initiation of treatment and evidence of rapidly progressing disease ${ }^{51}$. TEMPO 4:4 showed that benefit is sustained over time ${ }^{52}$.

In 2018, tolvaptan was approved by the US Food and Drug Administration for the purpose of slowing decline in kidney function in adults at risk of rapidly progressing ADPKD. This decision was based on additional information provided by the 
REPRISE trial, which demonstrated slowing in the deterioration of renal function, even in the later stages of renal failure ${ }^{8}$.

Currently, more than 6,000 patients with ADPKD are being treated with tolvaptan around the world. However, tolvaptan does have side effects. It markedly impairs urinary concentrating ability and therefore patients experience polyuria, nocturia, and polydipsia ${ }^{7,8}$. In addition, a small proportion of patients develop liver function abnormalities; it appears that whereas some of these abnormalities can be significant, all resolve upon drug discontinuation $^{53}$. This rare drug-induced liver injury led to the institution of a risk evaluation and mitigation strategy with monthly liver enzyme tests for the first 18 months and then at 3-month intervals.

A few other drugs, such as mammalian target of rapamycin (mTOR) inhibitors, somatostatin analogues, and bosutinib, also underwent clinical trials but failed to show any positive effect on disease progression ${ }^{54-57}$. Recommendations for the management of ADPKD are shown in Figure 1.

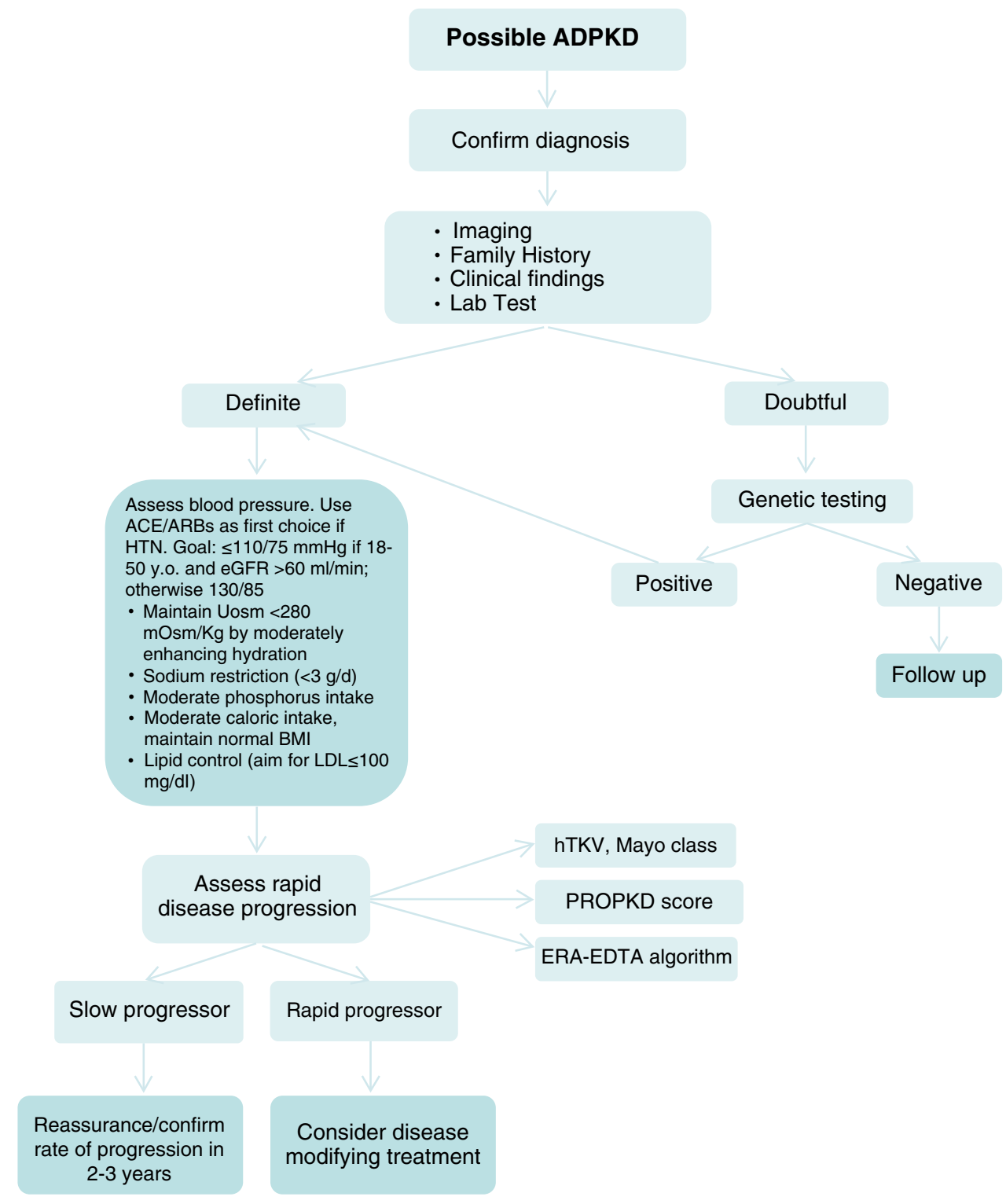

Figure 1. Diagnosis and management of autosomal dominant polycystic kidney disease. ACE/ARB, angiotensin-converting enzyme/angiotensin receptor blocker; ADPKD, autosomal dominant polycystic kidney disease; BMI, body mass index; eGFR, estimated glomerular filtration rate; ERA-EDTA, European Renal Association-European Dialysis and Transplant Association; hTKV, height-adapted total kidney volume; HTN, hypertension; LDL, low-density lipoprotein; PROPKD, Predicting Renal Outcome in Polycystic Kidney Disease; Uosm, urine osmolality. Modified from Chebib et al. ${ }^{27}$ and Chebib et al. ${ }^{42}$. 
Many new drugs are being tested, and it is probable that more than one drug will be needed to target the different abnormal pathways found in PKD cells.
Grant information

This work was funded by the ISCIII: RETIC REDINREN RD16/0009 FIS FEDER FUNDS (PI15/01824 and PI16/01998) and the Catalan Government (AGAUR 2014/SGR-1441).

The funders had no role in study design, data collection and analysis, decision to publish, or preparation of the manuscript.
1. Grantham JJ: Clinical practice. Autosomal dominant polycystic kidney disease. N Engl J Med. 2008; 359(14): 1477-85. PubMed Abstract | Publisher Full Text

2. The polycystic kidney disease 1 gene encodes a $14 \mathrm{~kb}$ transcript and lies within a duplicated region on chromosome 16. The European Polycystic Kidney Disease Consortium. Cell. 1994; 78(4): 725. PubMed Abstract

3. Mochizuki T, Wu G, Hayashi T, et al:: PKD2, a Gene for Polycystic Kidney Disease That Encodes an Integral Membrane Protein. Science. 1996; 272(5266): 1339-42.

PubMed Abstract | Publisher Full Text

4. F Audrézet MP, Cornec-Le Gall E, Chen JM, et al.: Autosomal dominant polycystic kidney disease: Comprehensive mutation analysis of PKD1 and PKD2 in 700 unrelated patients. Hum Mutat. 2012; 33(8): 1239-50. PubMed Abstract | Publisher Full Text | F1000 Recommendation

5. F Torra R, Badenas C, Darnell A, et al.: Linkage, clinical features, and prognosis of autosomal dominant polycystic kidney disease types 1 and 2. J Am Soc Nephrol. 1996; 7(10): 2142-51. PubMed Abstract | F1000 Recommendation

6. Cornec-Le Gall E, Audrézet MP, Le Meur Y, et al.: Genetics and Pathogenesis of Autosomal Dominant Polycystic Kidney Disease: 20 Years On. Hum Mutat. 2014; 35(12): 1393-406.

PubMed Abstract | Publisher Full Text

7. F Torres VE, Chapman AB, Devuyst O, et al:: Tolvaptan in Patients with Autosomal Dominant Polycystic Kidney Disease. N Engl J Med. 2012; 367(25): 2407-18.

PubMed Abstract | Publisher Full Text | Free Full Text | F1000 Recommendation

8. F Torres VE, Chapman AB, Devuyst O, et al:: Tolvaptan in Later-Stage Autosomal Dominant Polycystic Kidney Disease. N Engl J Med. 2017; 377(20): 1930-1942.

PubMed Abstract | Publisher Full Text | F1000 Recommendation

9. F Porath B, Gainullin VG, Cornec-Le Gall E, et al:: Mutations in GANAB, Encoding the Glucosidase Il $\alpha$ Subunit, Cause Autosomal-Dominant Polycystic Kidney and Liver Disease. Am J Hum Genet. 2016; 98(6): 1193-1207. PubMed Abstract | Publisher Full Text | Free Full Text | F1000 Recommendation

10. F Cornec-Le Gall E, Olson RJ, Besse W, et al.: Monoallelic Mutations to DNAJB11 Cause Atypical Autosomal-Dominant Polycystic Kidney Disease. Am J Hum Genet. 2018; 102(5): 832-844.

PubMed Abstract | Publisher Full Text | Free Full Text | F1000 Recommendation

11. Eckardt KU, Alper SL, Antignac C, et al.: Autosomal dominant tubulointerstitial kidney disease: diagnosis, classification, and management--A KDIGO consensus report. Kidney Int. 2015; 88(4): 676-83.

PubMed Abstract | Publisher Full Text

12. Perales MA, Schwartz DH, Fabry JA, et al.: A vaccinia-gp160-based vaccine but not a gp160 protein vaccine elicits anti-gp160 cytotoxic $T$ lymphocytes in some HIV-1 seronegative vaccinees. J Acquir Immune Defic Syndr Hum Retrovirol. 1995; 10(1): 27-35.

PubMed Abstract | Publisher Full Text

13. Peral B, Gamble V, Strong C, et al:: Identification of mutations in the duplicated region of the polycystic kidney disease 1 gene (PKD1) by a novel approach. Am J Hum Genet. 1997; 60(6): 1399-410. PubMed Abstract | Publisher Full Text | Free Full Text

14. Carrera $\mathrm{E}$, Maeder-Ingvar M, Rossetti $\mathrm{AO}$, et al:: Trends in risk factors, patterns and causes in hospitalized strokes over 25 years: The Lausanne Stroke Registry. Cerebrovasc Dis. 2007; 24(1): 97-103. PubMed Abstract | Publisher Full Text

15. F Cornec-Le Gall E, Chebib FT, Madsen CD, et al:: The Value of Genetic Testing in Polycystic Kidney Diseases Illustrated by a Family With PKD2 and COL4A1 Mutations. Am J Kidney Dis. 2018; 72(2): 302-8. PubMed Abstract | Publisher Full Text | Free Full Text | F1000 Recommendation

16. F Rossetti S, Hopp K, Sikkink RA, et al:: Identification of gene mutations in autosomal dominant polycystic kidney disease through targeted resequencing. J Am Soc Nephrol. 2012; 23(5): 915-33.
PubMed Abstract | Publisher Full Text | Free Full Text | F1000 Recommendation

17. Bullich G, Domingo-Gallego A, Vargas I, et al.: A kidney-disease gene pane allows a comprehensive genetic diagnosis of cystic and glomerular inherited kidney diseases. Kidney Int. 2018; 94(2): 363-71. PubMed Abstract | Publisher Full Text

18. $\mathrm{F}$ Bergmann C: Recent advances in the molecular diagnosis of polycystic kidney disease. Expert Rev Mol Diagn. 2017; 17(12): 1037-54. PubMed Abstract | Publisher Full Text | F1000 Recommendation

19. F Cornec-Le Gall E, Torres VE, Harris PC: Genetic Complexity of Autosomal Dominant Polycystic Kidney and Liver Diseases. J Am Soc Nephrol. 2018; 29(1) 13-23.

PubMed Abstract | Publisher Full Text | Free Full Text | F1000 Recommendation

20. F Swift O, Vilar E, Rahman B, et al:: Attitudes in Patients with Autosomal Dominant Polycystic Kidney Disease Toward Prenatal Diagnosis and Preimplantation Genetic Diagnosis. Genet Test Mol Biomarkers. 2016; 20(12) $741-6$.

PubMed Abstract | Publisher Full Text | F1000 Recommendation

21. Schrier RW, Brosnahan G, Cadnapaphornchai MA, et al: Predictors of autosomal dominant polycystic kidney disease progression. J Am Soc Nephrol. 2014; 25(11): 2399-418

PubMed Abstract | Publisher Full Text | Free Full Text

22. F Torres VE, Grantham JJ, Chapman AB, et al.: Potentially modifiable factors affecting the progression of autosomal dominant polycystic kidney disease. Clin J Am Soc Nephrol. 2011; 6(3): 640-7.

PubMed Abstract | Publisher Full Text | Free Full Text | F1000 Recommendation

23. F Cornec-Le Gall E, Audrézet MP, Rousseau A, et al:: The PROPKD Score: A New Algorithm to Predict Renal Survival in Autosomal Dominant Polycystic Kidney Disease. J Am Soc Nephrol. 2016; 27(3): 942-51.

PubMed Abstract | Publisher Full Text | Free Full Text | F1000 Recommendation

24. F Grantham JJ, Torres VE: The importance of total kidney volume in evaluating progression of polycystic kidney disease. Nat Rev Nephrol. 2016; 12(11): 667-77.

PubMed Abstract | Publisher Full Text | Free Full Text | F1000 Recommendation

25. F Yu ASL, Shen C, Landsittel DP, et al.: Baseline total kidney volume and the rate of kidney growth are associated with chronic kidney disease progression in Autosomal Dominant Polycystic Kidney Disease. Kidney Int. 2018; 93(3): 691-9.

PubMed Abstract | Publisher Full Text | Free Full Text | F1000 Recommendation

26. F Schrier RW, Abebe KZ, Perrone RD, et al.: Blood pressure in early autosomal dominant polycystic kidney disease. N Engl J Med. 2014; 371(24): 2255-66.

PubMed Abstract | Publisher Full Text | Free Full Text | F1000 Recommendation

27. F Chebib FT, Torres VE: Recent Advances in the Management of Autosomal Dominant Polycystic Kidney Disease. Clin J Am Soc Nephrol. 2018; 13(11): 1765-76.

PubMed Abstract | Publisher Full Text | Free Full Text | F1000 Recommendation

28. F Torres VE, Abebe KZ, Chapman AB, et al.: Angiotensin blockade in late autosomal dominant polycystic kidney disease. N Engl J Med. 2014; 371(24): 2267-76.

PubMed Abstract | Publisher Full Text | Free Full Text | F1000 Recommendation

29. F Nowak KL, You Z, Gitomer B, et al.: Overweight and Obesity Are Predictors of Progression in Early Autosomal Dominant Polycystic Kidney Disease. J Am Soc Nephrol. 2018; 29(2): 571-8.

PubMed Abstract | Publisher Full Text | Free Full Text | F1000 Recommendation

30. Torres VE, Bankir L, Grantham JJ: A case for water in the treatment of polycystic kidney disease. Clin J Am Soc Nephrol. 2009; 4(6): 1140-50. PubMed Abstract | Publisher Full Text

31. Klahr S, Breyer JA, Beck GJ, et al.: Dietary protein restriction, blood pressure control, and the progression of polycystic kidney disease. Modification of Diet in Renal Disease Study Group. J Am Soc Nephrol. 1995; 5(12): 2037-47. PubMed Abstract

32. F Messchendorp AL, Meijer E, Boertien WE, et al.: Urinary Biomarkers to 
Identify Autosomal Dominant Polycystic Kidney Disease Patients With a High Likelihood of Disease Progression. Kidney Int Rep. 2018; 3(2): 291-301. PubMed Abstract | Publisher Full Text | Free Full Text | F1000 Recommendation

33. F Pavik I, Jaeger P, Ebner L, et al.: Soluble klotho and autosomal dominan polycystic kidney disease. Clin J Am Soc Nephrol. 2012; 7(2): 248-57. PubMed Abstract | Publisher Full Text | Free Full Text | F1000 Recommendation

34. Meijer E, Bakker SJL, van der Jagt EJ, et al.: Copeptin, a surrogate marker of vasopressin, is associated with disease severity in autosomal dominant polycystic kidney disease. Clin J Am Soc Nephrol. 2011; 6(2): 361-8. PubMed Abstract | Publisher Full Text | Free Full Text

35. F Cornec-Le Gall E, Blais JD, Irazabal MV, et al:: Can we further enrich autosomal dominant polycystic kidney disease clinical trials for rapidly progressive patients? Application of the PROPKD score in the TEMPO trial. Nephrol Dial Transplant. 2017.

PubMed Abstract | Publisher Full Text | Free Full Text | F1000 Recommendation

36. F Irazabal MV, Rangel LJ, Bergstralh EJ, et al.: Imaging classification of autosomal dominant polycystic kidney disease: a simple model for selecting patients for clinical trials. J Am Soc Nephrol. 2015; 26(1): 160-72. PubMed Abstract | Publisher Full Text | Free Full Text | F1000 Recommendation

37. Magistroni R, Corsi C, Martí T, et al.: A Review of the Imaging Techniques for Measuring Kidney and Cyst Volume in Establishing Autosomal Dominant Polycystic Kidney Disease Progression. Am J Nephrol. 2018; 48(1): 67-78. PubMled Abstract | Publisher Full Text

38. $\mathrm{F}$ Bhutani $\mathrm{H}$, Smith $\mathrm{V}$, Rahbari-Oskoui $\mathrm{F}$, et al: A comparison of ultrasound and magnetic resonance imaging shows that kidney length predicts chronic kidney disease in autosomal dominant polycystic kidney disease. Kidney Int. 2015; 88(1): 146-51.

PubMed Abstract | Publisher Full Text | Free Full Text | F1000 Recommendation

39. Gansevoort RT, Arici M, Benzing T, et al: Recommendations for the use of tolvaptan in autosomal dominant polycystic kidney disease: a position statement on behalf of the ERA-EDTA Working Groups on Inherited Kidney Disorders and European Renal Best Practice. Nephrol Dial Transplant. 2016; 31(3): 337-48.

PubMed Abstract | Publisher Full Text | Free Full Text

40. Wyatt CM, Le Meur Y: REPRISE: tolvaptan in advanced polycystic kidney disease. Kidney Int. 2018; 93(2): 292-5 PubMed Abstract | Publisher Full Text

41. Furlano M, Loscos I, Martí T, et al:: Autosomal Dominant Polycystic Kidney Disease: Clinical Assessment of Rapid Progression. Am J Nephrol. 2018; 48(4): 308-17.

PubMed Abstract | Publisher Full Text

42. F Chebib FT, Perrone RD, Chapman AB, et al:: A Practical Guide for Treatment of Rapidly Progressive ADPKD with Tolvaptan. J Am Soc Nephrol. 2018; 29(10): 2458-70.

PubMed Abstract | Publisher Full Text | Free Full Text | F1000 Recommendation

43. F Lantinga MA, Casteleijn NF, Geudens A, et al.: Management of renal cyst infection in patients with autosomal dominant polycystic kidney disease: a systematic review. Nephrol Dial Transplant. 2017; 32(1): 144-50. PubMed Abstract | Publisher Full Text | F1000 Recommendation

44. El-Damanawi R, Harris T, Sandford RN, et al:: Patient Survey of current water Intake practices in autosomal dominant Polycystic kidney disease: the SIPs survey. Clin Kidney J. 2017; 10(3): 305-9. PubMed Abstract | Publisher Full Text | Free Full Text

45. Wong ATY, Mannix C, Grantham JJ, et al.: Randomised controlled trial to determine the efficacy and safety of prescribed water intake to prevent kidney failure due to autosomal dominant polycystic kidney disease (PREVENTADPKD). BMJ Open. 2018; 8(1): e018794.

PubMed Abstract | Free Full Text

46. F Clark WF, Sontrop JM, Huang SH, et al.: Hydration and Chronic Kidney Disease Progression: A Critical Review of the Evidence. Am J Nephrol. 2016; 43(4): 281-92. PubMed Abstract | Publisher Full Text | F1000 Recommendation

47. F Warner G, Hein KZ, Nin V, et al:: Food Restriction Ameliorates the Development of Polycystic Kidney Disease. J Am Soc Nephrol. 2016; 27(5): 1437-47.

PubMed Abstract | Publisher Full Text | Free Full Text | F1000 Recommendation

48. F Kipp KR, Rezaei M, Lin L, et al.: A mild reduction of food intake slows disease progression in an orthologous mouse model of polycystic kidney disease. Am J Physiol Renal Physiol. 2016; 310(8): F726-F731. PubMed Abstract | Publisher Full Text | Free Full Text | F1000 Recommendation

49. F Cadnapaphornchai MA, George DM, McFann K, et al:: Effect of pravastatin on total kidney volume, left ventricular mass index, and microalbuminuria in pediatric autosomal dominant polycystic kidney disease. Clin J Am Soc Nephrol. 2014; 9(5): 889-96.

PubMed Abstract | Publisher Full Text | Free Full Text | F1000 Recommendation

50. Brosnahan GM, Abebe KZ, Rahbari-Oskoui FF, et al.: Effect of Statin Therapy on the Progression of Autosomal Dominant Polycystic Kidney Disease. A Secondary Analysis of the HALT PKD Trials. Curr Hypertens Rev. 2017; 13(2): 109-20.

PubMed Abstract | Publisher Full Text | Free Full Text

51. European Medicines Agency: Assessment report: Jinarc. Procedure No. EMEA/ H/C/002788/0000. EMA/154879/2015. London, England: European Medicines Agency: 2015. Reference Source

52. F Torres VE, Chapman AB, Devuyst O, et al: Multicenter, open-label, extension trial to evaluate the long-term efficacy and safety of early versus delayed treatment with tolvaptan in autosomal dominant polycystic kidney disease: the TEMPO 4:4 Trial. Nephrol Dial Transplant. 2018; 33(3): 477-489. PubMed Abstract | Publisher Full Text | Free Full Text | F1000 Recommendation

53. Watkins PB, Lewis JH, Kaplowitz N, et al:: Clinical Pattern of Tolvaptan Associated Liver Injury in Subjects with Autosomal Dominant Polycystic Kidney Disease: Analysis of Clinical Trials Database. Drug Saf. 2015; 38(1): 1103-13.

PubMed Abstract | Publisher Full Text | Free Full Text

54. F Serra AL, Poster D, Kistler AD, et al:: Sirolimus and kidney growth in autosomal dominant polycystic kidney disease. N Engl J Med. 2010; 363(9): 820-9. PubMed Abstract | Publisher Full Text | F1000 Recommendation

55. Tesar V, Ciechanowski K, Pei Y, et al.: Bosutinib versus Placebo for Autosoma Dominant Polycystic Kidney Disease. J Am Soc Nephrol. 2017; 28(11): 3404-13. PubMed Abstract | Publisher Full Text | Free Full Text

56. F Walz G, Budde K, Mannaa M, et al.: Everolimus in patients with autosoma dominant polycystic kidney disease. N Engl J Med. 2010; 363(9): 830-40. PubMed Abstract | Publisher Full Text | F1000 Recommendation

57. F Meijer E, Visser FW, van Aerts RMM, et al.: Effect of Lanreotide on Kidney Function in Patients With Autosomal Dominant Polycystic Kidney Disease: The DIPAK 1 Randomized Clinical Trial. JAMA. 2018; 320(19): 2010-9. PubMed Abstract | Publisher Full Text | Free Full Text | F1000 Recommendation 


\section{Open Peer Review}

\section{Current Peer Review Status:}

\section{Editorial Note on the Review Process}

Faculty Reviews are review articles written by the prestigious Members of Faculty Opinions. The articles are commissioned and peer reviewed before publication to ensure that the final, published version is comprehensive and accessible. The reviewers who approved the final version are listed with their names and affiliations.

\section{The reviewers who approved this article are:}

\section{Version 1}

\section{John Sayer (iD} Institute of Genetic Medicine, Newcastle University, Newcastle upon Tyne, NE1 3BZ, UK Competing Interests: No competing interests were disclosed.

\section{Chang-Lin Mei}

Kidney Institute, Department of Nephrology, Shanghai Changzheng Hospital, Second Military Medical University, Shanghai, China

Competing Interests: No competing interests were disclosed.

The benefits of publishing with F1000Research:

- Your article is published within days, with no editorial bias

- You can publish traditional articles, null/negative results, case reports, data notes and more

- The peer review process is transparent and collaborative

- Your article is indexed in PubMed after passing peer review

- Dedicated customer support at every stage

For pre-submission enquiries, contact research@f1000.com 